\title{
UJI EFEK ANTIBAKTERI JAMUR ENDOFIT AKAR TUMBUHAN BAKAU (SONNERATIA ALBA) TERHADAP BAKTERI STAPHYLOCOCCUS AUREUS DAN ESCHERICHIAE COLI
}

\author{
${ }^{1}$ Titi L. Faraknimella \\ ${ }^{2}$ Robert Bara \\ ${ }^{2}$ Pemsi M. Wowor \\ ${ }^{2}$ Jimmy Posangi
}

\author{
${ }^{1}$ Kandidat Skripsi Fakultas Kedokteran Universitas Sam Ramtulangi \\ ${ }^{2}$ Bagian Farmakologi dan Terapi Fakultas Kedokteran, Universitas Sam Ratulangi Manado \\ Email: titi.faraknimella@yahoo.com
}

\begin{abstract}
Mangrove has been known long to have many benefits. One of the mangrove species that believed to have antimicrobial effects is Sonneratia alba. The objective of the study was to evaluate any antibacterial effect of the endophytic fungi isolated from the roots of Sonneratia alba toward the growth of Staphylococcus aureus and Eschericiae coli, using the combination method of PDA (Potato Dextrose Agar) and NA (Nutrient Agar). From the result we found two types of endophytes. Black and white colored fungus obtained from Sonneratia alba roots. Both fungi have the effect to inhibit the growth of Staphylococcus aureus and Eschericiae coli bacterial tested.
\end{abstract}

Keywords: endophyte, Sonneratia alba, antibacterial, staphylococcus aureus, escherichiae coli.

\begin{abstract}
Abstrak: Tumbuhan bakau sejak lama telah diketahui memiliki banyak khasiat. Salah satu jenis tumbuhan bakau yang diyakini memiliki efek antimikroba adalah Sonneratia alba. Penelitian ini dilakukan bertujuan untuk melihat adanya efek antibakteri dari jamur endofit yang diambil dari akar tumbuhan bakau Sonneratia alba terhadap pertumbuhan bakteri Staphylococcus aureus dan Eschericiae coli. Metode penilitian yang digunakan dengan cara kombinasi PDA (Potato Dextrose Agar) dan NA (Nutrient Agar). Hasil penelitian di dapatkan dua jenis miselia jamur endofit. Jamur endofit berwarna hitam dan berwarna putih diperoleh dari akar tumbuhan bakau Sonneratia alba. Kedua jenis jamur ini memiliki efek daya hambat pada bakteri yang diujikan yaitu Staphylococcus aureus dan Escherichiae Coli.
\end{abstract}

Kata kunci: jamur endofit, Sonneratia alba, antibakteri, staphylococcus aureus, escherichiae coli.

Bakteria dalahsalah satu kelompok mikroorganisme bersel tunggal dengan konfigurasi prokariotik (tidak mempunyai selubung inti). Bentuk DNA bakteri ialah sirkuler, panjang dan biasa disebut nukleoid. ${ }^{1}$ Bakteri pada umumnya mempunyai ukuran sel 0,5-1,0 $\mu \mathrm{m}$ kali 2,0$5,0 \mu \mathrm{m}^{2}$

Struktur bakteri terdiri dari inti/nukleus, sitoplasma, membran sitoplasma, dinding sel, kapsul, flagel, pili/fimbriae dan endospora. Inti/nukleus memiliki benang DNA yang panjangnya kira-kira $1 \mathrm{~mm}$. Dinding sel berfungsi untuk menjaga tekanan osmotik, pembelahan sel, biosintesis, diterminan dari antigen permukaan bakteri. ${ }^{2}$

Antibiotika adalah senyawa kimia yang dihasilkan oleh mikroorganisme (khususnya dihasilkan oleh fungi) atau 
dihasilkan secara sintetik yang dapat membunuh atau menghambat perkembangan bakteri dan organisme lain. Antibiotika diklasifikasikan berdasarkan cara kerja dan spektrum kerja. ${ }^{3}$

Resistensi adalah terhambatnya pertumbuhan bakteri dengan pemberian antibiotik secara sistemik dengan dosis normal yang seharusnya atau kadar hambat minimalnya. Penyebab utama resistensi antibiotika adalah penggunaan antibiotika yang meluasdan irasional. ${ }^{3}$

Sekitar 300.000 jenis tanaman yang tersebar di muka bumi ini, masing-masing tanaman mengandung satu atau lebih mikroba endofit yang terdiri dari bakteri dan jamur. Salah satu tumbuhan berkhasiat obat yang memiliki banyak manfaat adalah tumbuhan bakau Sonnertaia alba. ${ }^{4}$ Kelompok Sonneratia adalah sumber yang kaya tannin yang dikenal sebagai antimikroba. Pada penelitian sebelumnya daun tumbuhan bakau Sonneratia digunakan untuk antimikroba dan anti diabetes. $^{5}$

Berdasarkan hal tersebut diatas, peneliti tertarik untuk mengetahui potensi jamur endofit yang terdapat di dalam akar tumbuhan bakau Sonneratia alba sebagai obat antibakteri yang akan diujicobakan terhadap bakteeri Staphylococcus aureus dan Escherichiae coli.

\section{BAHAN DAN METODE PENELITIAN}

Penelitian ini merupakan penelitian eksperimental yang dilakukan sejak bulan November 2013 sampai dengan Januari 2014 dan penelitian ini dilakukan di Laboratorium Farmakologi Fakultas Kedokteran Universitas Sam Ratulangi.

\section{Isolasi jamur endofit}

Akar tumbuhan bakau jenis Sonneratia alba diambil dari daerah wisata di Tasik Ria Minahasa dan dibersihkan. Akar bakau yang telah diambil kemudian dipotong kirakira $5 \mathrm{~cm}$ dan direndam dalam larutan etanol $70 \%$ selama 30 detik untuk menghindari kontaminasi silang jamur epifit. Akar yang telah direndam menggunakan etanol $70 \%$ kemudian di potong ditengah sekitar $1 \mathrm{~cm}$ menggunakan scalpel.Potongan tersebut selanjutnya ditanam pada media agar yang dibuat dari PDA (Potato Dextrose Agar) di dalam cawan petri. Kloramfenikol 0,2 g/L ditambahkan sebelumnya kedalam media agar tersebut untuk mencegah pertumbuhan bakteri endofit. Sebelumnya media pertumbuhan jamur dalam cawan petri disterilisasi terlebih dahulu menggunakan otoklaf. Inokulasi sampel dilakukan diatas cawan petri dan tiap cawan berisi 1 potongan sampel. Tutup cawan petri yang berisi akar bakau tersebut (sealing), kemudian simpan pada suhu kamar $\left(25^{\circ} \mathrm{C}\right)$ selama 1-2 X 24 jam untuk menumbuhkan jamur. Setelah kurang lebih 2 - 3 hari akan terlihat pertumbuhan dari jamur disekitar sampel yang telah diletakkan dimedia agar. Dalam 1 akar bakau yang ditanam dapat menghasilkan beberapa pertumbuhan jamur yang berbeda.

\section{Pemurnian Jamur Endofit}

Miselia dari jamur yang telah tumbuh di ambil dengan cara ditusuk menggunakan kawat ose steril kemudian dipindahkan ke media PDA lainnya. Pemurnian ini bertujuan untuk memisahkan koloni endofit dengan morfologi berbeda untuk dijadikan isolate tersendiri.Simpan pada suhu ruangan selama 3-7 X 24 jam.

\section{Pengujian Aktivitas Antibakteri Penyiapan bakteri uji}

Nutrien agar ditimbang sebanyak 23 gram dan dilarutkan dalam 1 liter akuades. $\mathrm{pH}$ diukur hingga mencapai 6,8. Media kemudian disterilkan dalam otoklaf pada suhu $121^{\circ} \mathrm{C}$ selama 15 menit. Media selanjutnya dituang dalam tabung reaksi sebanyak $7 \mathrm{ml}$ dan dibiarkan mengeras dengan kemiringan $15^{\circ}$. Brain Heart Infusion (BHI) ditimbang sebanyak $37 \mathrm{~g}$ kemudian dilarutkan dalam $1 \mathrm{~L}$ akuades. Media kemudian disterilisasi dengan otoklaf pada suhu $121^{\circ} \mathrm{C}$ selama 15 menit. Media selanjutnya dituang ke dalam tabung reaksi sebanyak $5 \mathrm{ml}$ untuk selanjutnya digunakan sebagai media suspensi bakteri. Bakteri dikultur pada agar miring dengan 
cara mengambil koloni dengan kawat ose steril dan dimasukkan ke dalam media BHI. Kekeruhan bakteri distandarisasi dengan Larutan kekeruhan Mc. Farland. Suspensi bakteri kemudian digoreskan dengan menggunakan lidi kapas steril di atas permukaan media kombinasi. Jamur yang telah tumbuh pada media PDA kemudian dipotong berbentuk tabung dan diletakkan pada media kombinasi PDA (Potato Dextrose Agar) dan NA (Nutrient Agar) yang telah ditanami oleh bakteri uji.

\section{Uji kemampuan hambat jamur endofit}

Penanaman jamur dilakukan masingmasing 5 sampel jamur berbeda di 5 tempat pada 1 cawan petri dengan jarak yang sama. Kloramfenikol dilarutkan sebanyak 2 $\mathrm{mg} / \mathrm{ml}$, kertassaring kemudian dicelup kedalam larutan antibiotik tersebut kemudian diletakkan ditengah-tengah dari media, selanjutnya diinkubasi pada suhu kamar $\left(25^{\circ} \mathrm{C}\right)$. Jamur yang memiliki efektivitas dengan daya hambat dikultur kembali dan diuji efektivitasnya dengan pengulangan sebanyak 5 kali. Pengamatan dilakukan dalam kurun waktu 2-3 x 24 jam sampai terlihat zona hambat di sekitar pertumbuhan jamur.

\section{Pengukuran Zona Hambat}

Pengukuran zona hambat dilakukan dengan menggunakan pengaris dengan cara membalik cawan petri dan mengukur diameter daerah jernih (clear zone).

\section{HASIL PENILITIAN}

Dari hasil penelitian yang dilakukan di dapatkan dua jenis miselia jamur endofit. Jamur endofit berwarna hitam dan berwarna putih diperoleh dari akar tumbuhan bakau Sonneratia alba yang dikultur pada media Potato Dekstrose Agar. Jamur endofit yang diisolasi dari akar bakau Sonneratia alba dapat dilihat pada Gambar 1.

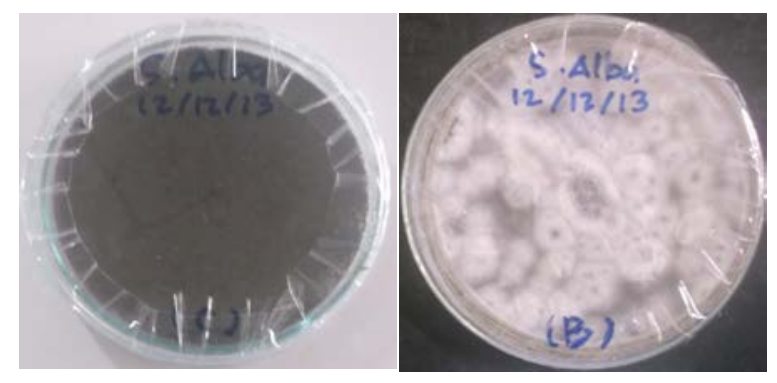

Gambar 1. Isolat jamur endofit yang diisolasi dari akar bakau Sonneratia alba. Hitam (kiri) dan Putih (kanan)

Tabel 1. Hasil pengujian daya hambat jamur endofit akar bakau Sonneratia alba pada bakteri Staphylococcus aureus dan Escherichiae coli.

\begin{tabular}{|c|c|c|c|c|c|}
\hline \multirow[t]{2}{*}{ NO } & \multirow{2}{*}{$\begin{array}{c}\text { Diameter } \\
\text { jamur } \\
(\mathrm{cm})\end{array}$} & \multicolumn{2}{|c|}{$\begin{array}{l}\text { Diameter/Luas zona hambat } \\
\text { Staphylococcus aureus }\end{array}$} & \multicolumn{2}{|c|}{$\begin{array}{c}\text { Diameter/Luas zona hambat } \\
\text { Escherichiae coli }\end{array}$} \\
\hline & & Hitam & Putih & Hitam & Putih \\
\hline 1 & 1 & $1,80 / 1,76$ & $1,90 / 2,05$ & $1,60 / 1,22$ & $1,80 / 1,76$ \\
\hline 2 & 1 & $1,90 / 2,05$ & $2,00 / 2,36$ & $1,50 / 0,98$ & $1,80 / 1,76$ \\
\hline 3 & 1 & $1,90 / 2,05$ & $2,00 / 2,36$ & $1,70 / 1,48$ & $1,70 / 1,48$ \\
\hline 4 & 1 & $1,70 / 1,48$ & $2,00 / 2,36$ & $1,90 / 2,05$ & $1,70 / 1,48$ \\
\hline 5 & 1 & $1,80 / 1,76$ & $2,10 / 2,68$ & $1,90 / 2,05$ & $1,80 / 1,76$ \\
\hline $\begin{array}{l}\text { Rata- } \\
\text { rata/SD }\end{array}$ & 1 & $1,82 / 0,08$ & $2,00 / 0,07$ & $1,72 / 0,18$ & $1,76 / 0,05$ \\
\hline $\begin{array}{c}\text { Kontrol } \\
(+)\end{array}$ & 1,8 & 1,9 & 2,0 & 1,6 & 1,7 \\
\hline \multicolumn{2}{|c|}{ Rata-rata kontrol (+) } & \multicolumn{2}{|c|}{1,95} & \multicolumn{2}{|c|}{1,65} \\
\hline
\end{tabular}




\section{BAHASAN}

Penelitian ini menggunakan dua jenis miselia jamur endofit berwarna hitam dan putih yang diisolasi dari akar bakau Sonneratia alba dan diuji daya hambatnya terhadap bakteri uji yaitu Staphylococcus aureus dan Escherichiae coli. Pengukuran zona hambat yang terbentuk dilakukan setelah diinkubasi selama 1 x 24 jam. Dari penelitian yang dilakukan terhadap kedua jenis bakteri uji didapatkan daya hambat antibakteri oleh jamur endofit yang diisolasi dari akar bakau Sonneratia alba yaitu jamur dengan miselia berwarna putih lebih kuat dibandingkan dengan jamur dengan miselia yang berwarna hitam. Hal ini mungkin dikarenakan beberapa faktor, antara lain : senyawa antibiotik yang diproduksi oleh miselia jamur yang berwarna putih lebih kuat dibandingkan dengan miselia jamur yang berwarna hitam. Selain itu tidak menutup kemungkinan bahwa konsentrasi pada miselia jamur yang berwarna putih tidaklah sama dengan yang berwarna hitam. Jamur dipotong dengan ukuran yang sama tanpa diketahui konsentrasi dari jamur tersebut. Berdasarkan hasil penelitian tersebut diatas maka dapat disimpulkan bahwa dua jenis isolat miselia jamur endofit berwarna putih dan hitam yang diisolasi dari akar bakau Sonneratia alba memiliki daya hambat terhadap pertumbuhan kedua bakteri uji yaitu Staphylococcus aureus dan Escherichiae coli. Penelitian ini menunjukan bahwa jamur tersebut memiliki daya hambat antibakteri yang signifikan. Penelitian ini hanya melihat adanya efek daya hambat pertumbuhan bakteri uji tanpa dilakukan identifikasi jamur endofit itu sendiri, sehingga perlu adanya penelitian lebih lanjut.

\section{SIMPULAN}

Berdasarkan hasil penelitian yang telah dilakukan maka dapat diambil suatu kesimpulan yaitu daya hambat pertumbuhan bakteri Staphylococcus aureus dan Escherichiae coli oleh Jamur Endofit yang diisolasi dari akar bakau Sonneratia alba memberikan hasil positif, yaitu terdapat penghambatan pertumbuhan terhadap kedua jenis bakteri tersebut.

\section{DAFTAR PUSTAKA}

1. Unismus. Bakteri. [Online]. [cited 2014 June 15]. Available from: http://www.digilib.unismus.ac.id/bakt eri.pdf.

2. Universitas Indonesia. Definisi Bakteri. [Online]. [cited 2014 June 15]. Available from: http://www.lib.ui.ac.id/file/definisi_b akteri.pdf.

3. E-journal. Antibiotik. [Online]. [cited 2014 June 15]. Available from: http://www.ejournal.uinmalang.ac.id/antibiotik.pdf.

4. Strobel GA, Daisy B. Bioprospecting For Microbial Endophytes and Their Natural Products. Microbiology and Molecular Biology Reviews. 2003;67(4):419-502.

5. Milon MA. International Journal Pharmaceutical Sciences and Research. Antioxidant, Cytotoxic and Antimicrobial Activity of Sonneratia Alba Bark. 2012. [Online]. [cited 2014 June 15]. Available from: http://www.researchgate.net/article.pd f. 